\title{
Total lead and its stable isotopes in the digestive gland of Octopus vulgaris as a fingerprint
}

\author{
J. Raimundo ${ }^{1,2, *}$, C. Vale ${ }^{1}$, M. Caetano ${ }^{1}$, R. Cesário ${ }^{1}$, I. Moura ${ }^{2}$ \\ ${ }^{1}$ IPIMAR - National Institute of Biological Resources, Av. Brasília, 1449-006 Lisbon, Portugal \\ ${ }^{2}$ REQUIMTE - CQFB, Department of Chemistry, Faculty of Sciences and Technology, New University of Lisbon, Qta Torre, \\ 2829-516 Monte da Caparica, Portugal
}

\begin{abstract}
We hypothesised that the isotopic signature of $\mathrm{Pb}$ in the digestive gland of the common octopus reflects the organisms' sources of $\mathrm{Pb}$, and investigated whether isotopic $\mathrm{Pb}$ ratios are useful in characterising octopus populations. A total of 47 Octopus vulgaris individuals were captured between November 2005 and September 2006 in 2 areas of the Portuguese coast, near Matosinhos (Area $\mathrm{A}_{;} \mathrm{NW}$ coast) and Olhão (Area $\mathrm{B}$; south coast), and digestive glands were analysed for total $\mathrm{Pb}$ and its stable isotopes. The same determinations were performed in 22 samples of surface sediments from the 2 areas. $\mathrm{Pb}$ concentrations in the digestive gland of specimens from Area B (2.8 to $13.0 \mu \mathrm{g}$ $\mathrm{g}^{-1}$ ) exceeded the values found in Area A (1.3 to $\left.8.3 \mathrm{\mu g} \mathrm{g}^{-1}\right)$. A similar pattern was found for the isotopic $\mathrm{Pb}$ ratios: ${ }^{206} \mathrm{~Pb} /{ }^{207} \mathrm{~Pb}$ was 1.173 to 1.185 for Area $\mathrm{A}$ and 1.165 to 1.172 for $\mathrm{B}^{2}{ }^{206} \mathrm{~Pb} /{ }^{208} \mathrm{~Pb}$ was 0.476 to 0.487 for Area A and 0.318 to 0.483 for B. The different signatures of the digestive glands are in line with those observed in the surface sediments of the 2 coastal areas (e.g. ${ }^{206} \mathrm{~Pb} /{ }^{207} \mathrm{~Pb}$ was 1.179 to 1.207 for Area A and 1.171 to 1.181 for B). However, the isotopic Pb signature of octopus was less radiogenic than that of sediments. Because octopus has a short life span (up to $24 \mathrm{mo}$ ) the signature reflects recent sources of $\mathrm{Pb}$ that have a less radiogenic signature. The $\mathrm{Pb}$ signature of surface sediments tends to integrate the record of the previous few years or decades, due to the frequent resuspension of the upper layer of coastal sediments. The mixing of sediments deposited during those periods results in higher isotopic $\mathrm{Pb}$ ratios (more radiogenic). The consistent differences between the 2 areas, in sediments and octopus, points towards the isotopic $\mathrm{Pb}$ signature as a possible useful tool to distinguish octopus populations.
\end{abstract}

KEY WORDS: Cephalopods $\cdot$ Lead $\cdot$ Stable lead isotopes $\cdot$ Bioaccumulation $\cdot$ Portugal

\section{INTRODUCTION}

The marine biogeochemical cycle of $\mathrm{Pb}$ has been greatly affected by human activity in the last century (Komárek et al. 2008). Industrial emissions and gasoline exhaust fumes have led to an increase in $\mathrm{Pb}$ deposition into the marine environment (Alleman et al. 2000). In the past, understanding $\mathrm{Pb}$ bioaccumulation relied mainly on concentration measurements. Because $\mathrm{Pb}$ isotope ratios vary according to the origin of this element, the inclusion of these values in environmental studies allowed researchers to distinguish the pathways of $\mathrm{Pb}$ from distinct sources (Komárek et al.
2008). There are 4 stable isotopes with mass numbers: ${ }^{204} \mathrm{~Pb}$ (primordial), ${ }^{206} \mathrm{~Pb},{ }^{207} \mathrm{~Pb}$ and ${ }^{208} \mathrm{~Pb}$ (radiogenic). The last 3 isotopes are products of the radioactive decay of ${ }^{238} \mathrm{U},{ }^{235} \mathrm{U}$ and ${ }^{232} \mathrm{Th}$, respectively (Scheuhammer \& Templeton 1998). The isotopic composition of anthropogenic and natural $\mathrm{Pb}$ generally differs and is seldom affected by kinetic processes (Gobeil et al. 2001).

The high persistence of $\mathrm{Pb}$ in abiotic compartments and its accumulation in living organisms has allowed researchers to determine baseline values and spatial distribution of $\mathrm{Pb}$ in sediments and biota, and to study its behaviour in the coastal zone (e.g. Prego \& CobeloGarcia 2004). In the last decade, determination of $\mathrm{Pb}$ 
concentration in sediments has been coupled with measurement of $\mathrm{Pb}$ isotope ratios to better understand the fate of this element within coastal ecosystems. However, the isotopic $\mathrm{Pb}$ signature in marine organisms has been poorly documented. Only a few studies have indicated that biological samples can provide a fingerprint for sources of $\mathrm{Pb}$ (Spencer et al. 2000, Ip et al. 2005).

Octopus vulgaris, common octopus, is a benthic species and exclusively neritic, with the exception of the larval phase, which is planktonic. O. vulgaris has a short lifespan, fast growth and high reproductive potential (Rocha et al. 2001). This species is normally distributed on rocky, sandy and muddy bottoms (Mangold 1983). Octopus has been long considered to have a cosmopolitan occurrence in temperate and tropical seas (Roper et al. 1984), although a possible occurrence of cryptic species among $O$. vulgaris-like octopods is also reported (Guerra et al. 1999). Thus, the distribution of $O$. vulgaris in a strict sense may be restricted to the Mediterranean Sea and eastern Atlantic Ocean (Mangold 1983). Octopus undergoes vertical seasonal migrations, moving close to the shore for reproduction (Mangold \& von Boletzky 1973).

Bioaccumulation studies have reported that storage of $\mathrm{Pb}$ in cephalopods occurs mainly in the digestive gland (e.g. Miramand \& Bentley 1992, Nessim \& Riad 2003, Seixas et al. 2005, Bustamante et al. 2008, Raimundo \& Vale 2008). Furthermore, accumulated $\mathrm{Pb}$ levels appear to depend on the availability of $\mathrm{Pb}$ in water and food (Bustamante et al. 1998, Raimundo et al. 2004, 2005, Napoleão et al. 2005). However, to our knowledge no attempt has been made to clarify whether accumulated $\mathrm{Pb}$ values in the digestive gland reflect an anthropogenic versus natural origin.

Contrasting geomorphological features and oceanographic conditions were reported for the Portuguese coast (Fiuza 1983): the NW region is an exposed coast characterised by several estuarine systems crossing the shore, while the southern region is a sheltered coast with extensive inner coastal lagoons. The Iberian Peninsula is crossed by a giant massive sulphide deposit in the southern region (Iberian Pyrite Belt), mined since the Roman Age (Palanques et al. 1995), and has a relatively homogeneous isotopic $\mathrm{Pb}$ signature (Marcoux 1997). Water surveys have shown different availability of trace elements in the NW and southern coastal waters (Caetano \& Vale 2003). River flow regime and pyrite belt location were invoked as major factors influencing these differences. A similar geographic contrast was found for $\mathrm{Zn}, \mathrm{Pb}, \mathrm{Cd}$ and $\mathrm{Hg}$ concentrations in the digestive gland of Octopus vulgaris (Raimundo et al. 2004, Napoleão et al. 2005, Seixas et al. 2005): enhanced levels of $\mathrm{Pb}, \mathrm{Hg}$, and $\mathrm{Zn}$ were found in individuals from the south coast and higher accumulation of $\mathrm{Cd}$ was found in specimens captured in NW stations.

The 2 areas are, therefore, suitable for testing the hypothesis that the isotopic $\mathrm{Pb}$ signature in the digestive gland of octopus reflects the animals' sources of $\mathrm{Pb}$, and for investigating whether $\mathrm{Pb}$ isotope ratios are useful for characterising octopus populations. We measured total and stable $\mathrm{Pb}$ isotopes in the digestive gland of Octopus vulgaris from the NW and southern areas of Portugal, as well as $\mathrm{Al}$ and $\mathrm{Pb}$ concentrations and stable $\mathrm{Pb}$ isotopes in sediments, which we used to distinguish $\mathrm{Pb}$ signatures between the 2 areas.

\section{MATERIALS AND METHODS}

Samples. A total of 47 Octopus vulgaris individuals were collected between November 2005 and September 2006 from commercial catches landed in Matosinhos (NW coast; hereinafter Area A) and Olhão (southern coast; Area B). Specimens were captured within $6 \mathrm{n}$ miles $(9.7 \mathrm{~km})$ radius centred from each of Areas A and B (Fig. 1). Total body weight, mantle length and sex were determined for each individual. Specimens were stored in individual plastic bags and frozen $\left(-80^{\circ} \mathrm{C}\right)$ in order to minimise mobilisation of metals among organs and tissues (Martin \& Flegal 1975). In the laboratory, the digestive gland was totally removed under partially defrosted conditions without rupture of the tissue, then freezedried, grounded and homogenised.

Surface sediments were collected in February 2006 in Areas A (12 samples) and B (10 samples), using a Van Veen grab from RV 'Noruega'. The top $5 \mathrm{~cm}$ sediment layer was sampled. Each sediment sample was ovendried to constant weight at $40^{\circ} \mathrm{C}$, sieved through a $2 \mathrm{~mm}$ mesh and ground with an agate mortar.

Analytical methodology. Sample pre-treatment: Samples of digestive gland ( 200 mg) were digested with a mixture of $\mathrm{HNO}_{3}$ (supra pure, $65 \%$ v/v) and $\mathrm{H}_{2} \mathrm{O}_{2}$ (supra pure, $30 \% \mathrm{v} / \mathrm{v}$ ) at $60^{\circ} \mathrm{C}$ for $12 \mathrm{~h}, 100^{\circ} \mathrm{C}$ for $1 \mathrm{~h}$ and $1 \mathrm{~h}$ at $80^{\circ} \mathrm{C}$ according to Ferreira et al. (1990). Two mineralisation procedures were used for sediment samples: (1) digestion for $\mathrm{Al}$ quantification using HF (supra pure,

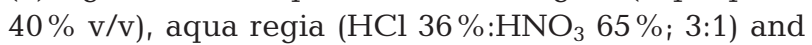
$\mathrm{H}_{3} \mathrm{BO}_{4}$ following Rantala \& Loring (1975); and (2) mineralisation for analysis of $\mathrm{Pb}$ concentration and stable $\mathrm{Pb}$ isotopes by using the first step of Procedure (1), and evaporating to near-dryness and eluting with $\mathrm{HNO}_{3}$ (double-distilled) and Milli-Q water (18.2 M $\mathrm{cm}$ ) (Caetano et al. 2007). Procedural blanks were prepared using the same analytical procedure and reagents, and included within each batch of 10 samples.

Methods: Al was analysed by flame atomic absorption spectrometry (Perkin Elmer AA100) with a nitrous oxide-acetylene flame and concentrations determined 


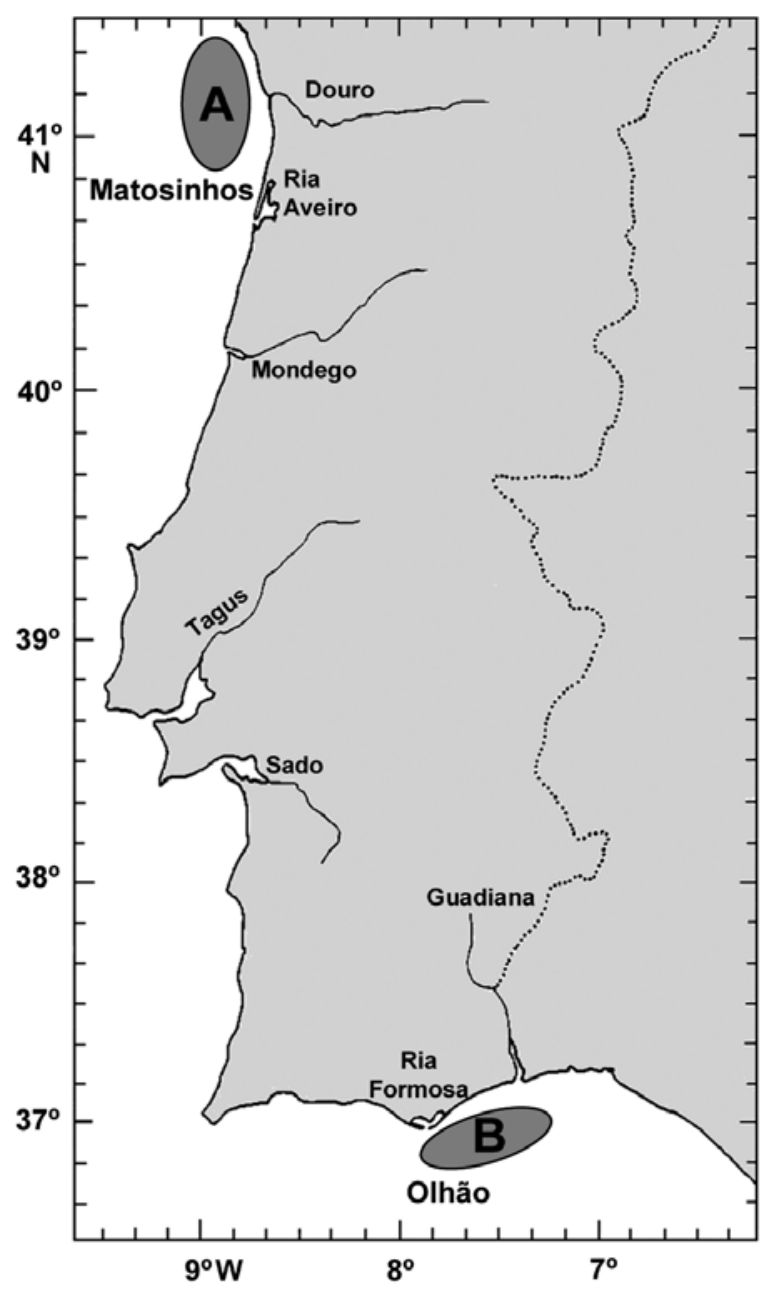

Fig. 1. Location of the 2 sampling sites on the Portuguese coast: A (Matosinhos) and B (Olhão)

with the standard addition method. Total $\mathrm{Pb}$ concentration and stable $\mathrm{Pb}$ isotopes $\left({ }^{206} \mathrm{~Pb},{ }^{207} \mathrm{~Pb}\right.$ and $\left.{ }^{208} \mathrm{~Pb}\right)$ were determined in the same samples but in separate runs using a quadropole inductively coupled plasma mass spectrometer (ICP-MS; Thermo Elemental, XSeries) equipped with a Peltier Impact bead spray chamber and a concentric Meinhard nebuliser. A 7 point calibration within a range of 1 to $100 \mu \mathrm{g} \mathrm{l}^{-1}$ was used to quantify total $\mathrm{Pb}$. The precision and accuracy of the $\mathrm{Pb}$ concentration measurements, determined through repeated analysis of reference materials (BCSS-1 and MESS-3 for sediment, and TORT-1 and TORT-2 lobster hepatopancreas for organisms), using ${ }^{115}$ In as the internal standard, was better than $2 \%$ (Table 1). Procedural blanks always accounted for $<1 \%$ of the total $\mathrm{Pb}$ in the samples. For $\mathrm{Pb}$ isotope determinations, between every 2 samples, corrections for mass fractionation were applied using NISTSRM981 reference material. The isotopic $\mathrm{Pb}$ composition of procedural blanks did not significantly influ- ence the ${ }^{206} \mathrm{~Pb} /{ }^{207} \mathrm{~Pb}$ and ${ }^{206} \mathrm{~Pb} /{ }^{208} \mathrm{~Pb}$ ratios. The coefficients of variation of the NIST-SRM981 reference material obtained in between-batch external quality control were $0.37 \%$ for ${ }^{206} \mathrm{~Pb} /{ }^{207} \mathrm{~Pb}$ and $0.22 \%$ for ${ }^{206} \mathrm{~Pb} /{ }^{208} \mathrm{~Pb}$ ratios.

Statistical analysis. Prior to statistical analysis, metal concentrations and biological parameters were tested for normality and equality of variances. The nonparametric Kruskal-Wallis test (KW H) was applied to all data in order to detect differences between metal concentrations and biological parameters and in the 2 study areas. The statistical analyses were performed using the STATISTICA 6.0 Statistical Software System.

\section{RESULTS}

\section{Biological parameters in octopus}

The octopus sampled in Area A included 13 males and 11 females, and the specimens in Area B were 12 males and 11 females. Size and weight of the sampled individuals varied over broad ranges: Area A, 125 to $170 \mathrm{~mm}$ and 578 to $1433 \mathrm{~g}$; Area B, 113 to $165 \mathrm{~mm}$ and 698 to 1520 g, respectively. Size, weight and sex were not significantly ( $p>0.05$ ) different between areas. Differences between sampling periods were also not significant ( $p>0.05)$.

\section{$\mathrm{Pb}$ concentration and isotopic ratios in digestive gland}

Levels of total $\mathrm{Pb}$ were significantly lower in Area A (Fig. 2a). Pb isotope ratios in specimens from Area A were significantly higher than those from Area B (Fig. 2b,c). No statistical differences $(p>0.05)$ were found between $\mathrm{Pb}$ concentration or isotopic $\mathrm{Pb}$ ratios and the measured biological parameters. Differences between sampling periods were also not significant.

Table 1. $\mathrm{Pb}$ and $\mathrm{Al}$ concentrations (mean $\pm \mathrm{SE}$ ) of lobster hepatopancreas (TORT-1 and TORT-2) and marine sediments (BCSS-1 and MESS-3) (National Research Council of Canada) in the present study and certified values; nd: not determined

\begin{tabular}{|llcc|}
\hline Standard & & $\begin{array}{c}\mathrm{Pb} \\
\left(\mu \mathrm{g} \mathrm{g}^{-1}, \mathrm{dry} w \mathrm{w}\right)\end{array}$ & $\begin{array}{c}\mathrm{Al} \\
(\%, \mathrm{dry} w \mathrm{w})\end{array}$ \\
\hline TORT-1 & Obtained & $9.4 \pm 1.9$ & $\mathrm{nd}$ \\
& Certified & $10.4 \pm 2$ & $\mathrm{nd}$ \\
TORT-2 & Obtained & $0.43 \pm 0.27$ & $\mathrm{nd}$ \\
& Certified & $0.35 \pm 0.13$ & $\mathrm{nd}$ \\
BCSS-1 & Obtained & $23.0 \pm 3.7$ & $6.56 \pm 0.17$ \\
& Certified & $22.7 \pm 3.4$ & $6.26 \pm 0.22$ \\
MESS-3 & Obtained & $22.1 \pm 3.1$ & $9.17 \pm 0.23$ \\
& Certified & $21.9 \pm 1.2$ & $8.59 \pm 0.23$ \\
\hline
\end{tabular}



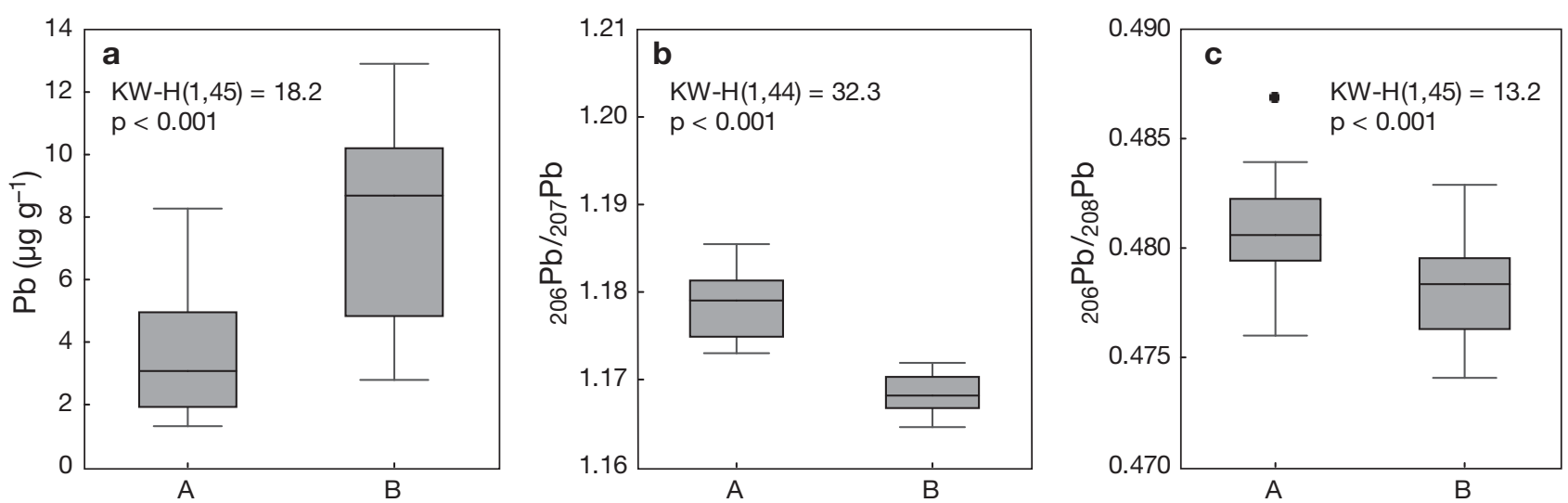

Fig. 2. Octopus vulgaris. (a) $\mathrm{Pb}$ concentrations ( $\mu \mathrm{g} \mathrm{g} \mathrm{g}^{-1}$ dry wt); (b) ${ }^{206} \mathrm{~Pb} /{ }^{207} \mathrm{~Pb}$ and (c) ${ }^{206} \mathrm{~Pb} /{ }^{208} \mathrm{~Pb}$ ratios in the digestive gland at Matosinhos (A) and Olhão (B). Data are median, 25th and 75th percentiles, minimum and maximum, outliers $(\bullet)$, Kruskal-

Wallis test $(\mathrm{KW} H)$ and $\mathrm{p}$

\section{$\mathrm{Al}$ and $\mathrm{Pb}$ concentrations in sediment}

$\mathrm{Al}$ content in surface sediments from Areas A and B ranged within broad intervals: 1.9 to $6.8 \%$ and 0.58 to
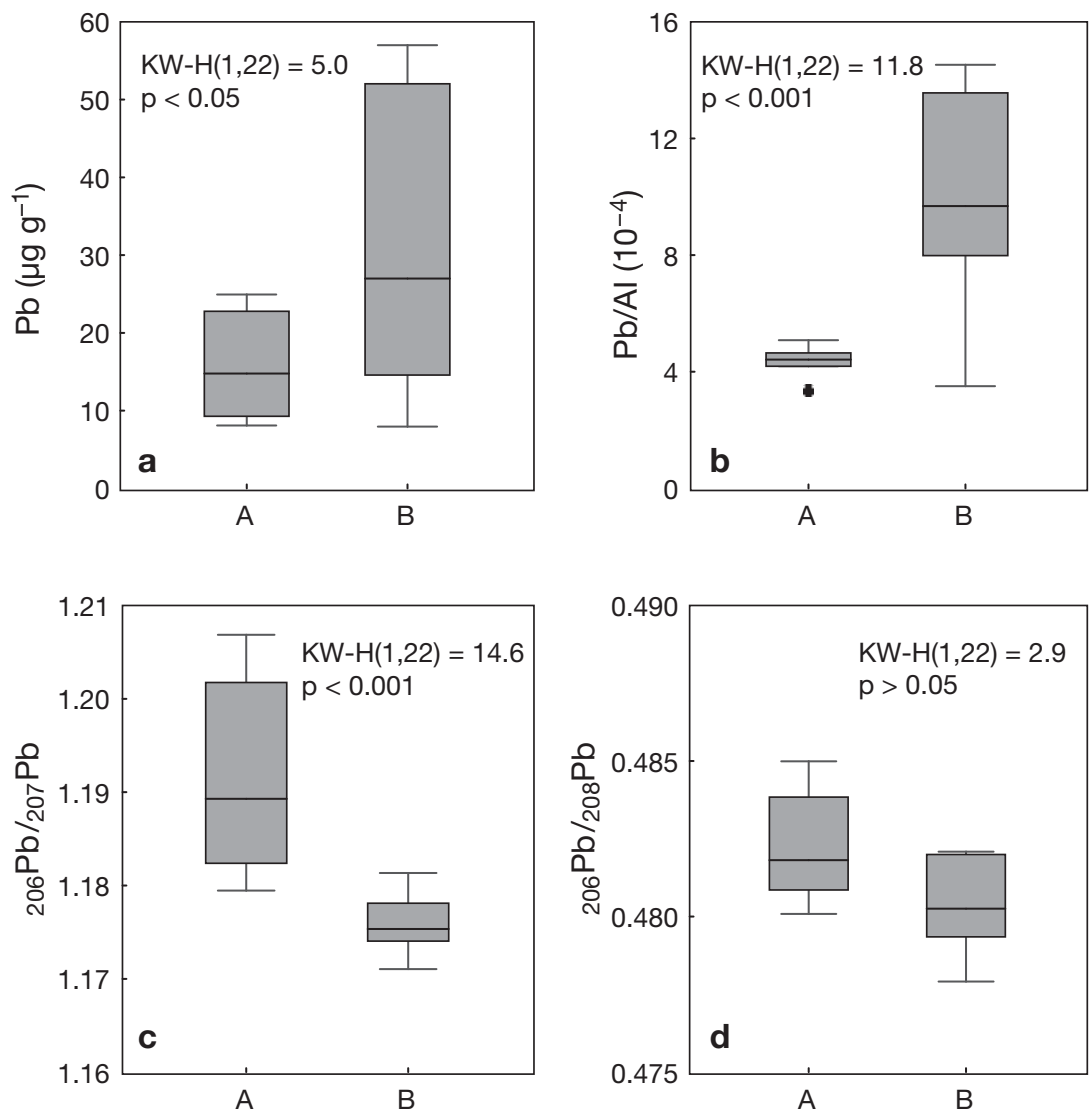

Fig. 3. (a) Pb concentrations ( $\mu \mathrm{g} \mathrm{g}{ }^{-1}$ dry wt) and (b) $\mathrm{Pb} / \mathrm{Al}\left(10^{-4}\right)$, (c) ${ }^{206} \mathrm{~Pb} /{ }^{207} \mathrm{~Pb}$ and (d) ${ }^{206} \mathrm{~Pb} /{ }^{208} \mathrm{~Pb}$ ratios in surface sediments at Matosinhos (A) and Olhão (B). Data are median, 25th and 75th percentiles, minimum and maximum, outliers $(\bullet)$, KruskalWallis test $(\mathrm{KW} \mathrm{H})$ and $\mathrm{p}$
$8.7 \%$, respectively. These results indicate that sediments sampled in the 2 areas present a wide mixture of coarse (low Al content) and fine-grained particles (high $\mathrm{Al}$ content). The sediment samples of the 2 areas showed no significant $(p>0.05)$ differences in $\mathrm{Al}$ content. When metal concentrations are compared in a sediment set containing different grain sizes it is recommended to normalise levels to $\mathrm{Al}$ in order to minimise differences associated with sediment nature (Windom et al. 1989). For this reason $\mathrm{Pb}$ concentrations in the present study were normalised to $\mathrm{Al}$ content. $\mathrm{Pb}$ concentrations varied in a wide range, with levels in Area B significantly higher than in Area A (Fig. 3). Normalising $\mathrm{Pb}$ to $\mathrm{Al}$ separated the 2 areas pronouncedly; elevated $\mathrm{Pb}$ concentrations in Area B were not due to a more abundant fine fraction. The values of $\mathrm{Pb} / \mathrm{Al}$ in Area $\mathrm{B}$ were significantly higher than those from Area A (Fig. 3b.

\section{Isotopic $\mathrm{Pb}$ ratios in sediment}

Surface sediments from Area A showed a more radiogenic signature of ${ }^{206} \mathrm{~Pb} /{ }^{207} \mathrm{~Pb}$ than those from Area B (Fig. 3c). Moreover, a broader range of this ratio was found in sediments from Area A. However, no significant differences of ${ }^{206} \mathrm{~Pb} /{ }^{208} \mathrm{~Pb}$ ratios were found between the 2 areas (Fig. 3d). 


\section{DISCUSSION}

The broad range of $\mathrm{Al}$ content in surface sediments indicates the existence of a wide combination of coarse and fine-grained materials in the 2 study areas. Despite that variability, $\mathrm{Pb} / \mathrm{Al}$ ratios were consistently higher in Area B. The elevated ratios appear to result mainly from the geological feature of the Iberian Pyrite Belt, since anthropogenic $\mathrm{Pb}$ sources were minor. Indeed, the narrow range of isotopic $\mathrm{Pb}$ signature of sediments $\left({ }^{206} \mathrm{~Pb} /{ }^{207} \mathrm{~Pb}\right.$ was 1.171 to 1.181$)$ matches data of Caetano et al. (2007) on sediments from Guadiana River, the main river that crosses the sulphide deposit area $\left({ }^{206} \mathrm{~Pb} /{ }^{207} \mathrm{~Pb}=1.172 \pm 0.003\right)$. The obtained isotopic $\mathrm{Pb}$ signature in coastal sediments from Area B suggests a mixing of particles derived from the Pyrite Belt and pre-industrial sediments, with minor inputs of anthropogenic $\mathrm{Pb}$ (Caetano et al. 2007). In contrast, sediments from Area A exhibited a broader range of ${ }^{206} \mathrm{~Pb} /{ }^{207} \mathrm{~Pb}$ ratios, suggesting that $\mathrm{Pb}$ concentration in sediments was influenced by $\mathrm{Pb}$ from various origins. The observed ${ }^{206} \mathrm{~Pb} /{ }^{207} \mathrm{~Pb}$ ratios (1.179 to 1.207 ) were comprised of values reported for sediments contaminated by industrial effluents (1.166 to 1.170; Sundby et al. 2005) and pre-pollution $\mathrm{Pb}$ signature as recorded in NW Spain (1.235; Kylander et al. 2005) or in preindustrial sediments from the North Atlantic (1.197 to 1.220; Sun 1980). Area A receives the discharges of the Douro River, which crosses an extensive rural area, and of the urban effluents of Porto (Caetano \& Vale 2003). The isotopic $\mathrm{Pb}$ signature of coarse and fine sediments from Area A may thus mirror the mixture of high-radiogenic background $\mathrm{Pb}$ and low-radiogenic contaminant $\mathrm{Pb}$ emissions of alkyl-lead gasoline (1.06 to 1.09; Gobeil et al. 2001).

$\mathrm{Pb}$ concentrations in the digestive gland of Octopus vulgaris captured in the 2 areas ranged within the intervals observed in previous studies (Raimundo et al. 2004, 2008, Napoleão et al. 2005). The elevated concentration of $\mathrm{Pb}$ in sediments (Area $\mathrm{B}$ ), as well as the $\mathrm{Pb} / \mathrm{Al}$ ratios, match the increased values in the digestive gland of specimens from the same area. This response to the environmental availability is consistent with findings of other cephalopod studies (Bustamante et al. 1998, Koyama et al. 2000, Raimundo et al. 2004, Napoleão et al. 2005). Our results do not allow for the evaluation of the preferential pathway of accumulation; however, given the sedentary habits of octopus, both water and food should be considered vehicles for $\mathrm{Pb}$ uptake. It is expected that $\mathrm{Pb}$ in sediments influences the levels existing in benthic organisms that constitute the octopus diet, including crabs and bivalves (Mangold 1983). The uptake of $\mathrm{Pb}$ from different pathways presupposes the accumulation of $\mathrm{Pb}$ with distinct signatures. Thus the observed signature is an integra- tion of all local sources. Specimens from Area B exhibited lower isotopic ratios $\left({ }^{206} \mathrm{~Pb} /{ }^{207} \mathrm{~Pb}\right.$ ratios were 1.165 to 1.172) than from Area A (1.173 to 1.185), mirroring the $\mathrm{Pb}$ signature of each area. This parallelism has been rarely reported for marine organisms.

However, isotopic signatures in octopus and sediments did not show the same range of values. These differences are consistent with findings from Ip et al. (2005) that showed lower isotopic Pb ratios in molluscs, crustaceans and fish than in sediments. Because octopus has a short lifespan (up to 24 mo; Mangold 1997), isotopic $\mathrm{Pb}$ ratios in the digestive gland should reflect recent sources of $\mathrm{Pb}$ that, in comparison to previous sources, have a less radiogenic signature. The 2 coastal areas are frequently subjected to suspension of surface sediments and settling events due to wave or wind storms. As a result, the isotopic $\mathrm{Pb}$ signature of the collected sediments tends to integrate the record of the previous few years or decades. This is why the Pb signature in sediments showed higher isotopic ratios than octopus tissues. The hypothesis of segregated accumulation of $\mathrm{Pb}$ isotopes by Octopus vulgaris or differential isotope detoxification is beyond the scope of this work. These results indicate that isotopic $\mathrm{Pb}$ signature in the digestive gland of octopus reflects the $\mathrm{Pb}$ sources of the animal and offers a useful tool for distinguishing octopus populations.

Acknowledgements. We thank H. de Pablo for the collection of the sediment samples and 5 anonymous reviewers for their comments and suggestions. J.R. is funded by a $\mathrm{PhD}$ fellowship provided by the 'Fundação para a Ciência e a Tecnologia' (FCT, Grant No. SFRH/BD/37730/2007).

\section{LITERATURE CITED}

Alleman LY, Hamelin B, Véron AJ, Miquel JC, Heussner S (2000) Lead sources and transfer in the coastal Mediterranean: evidence from stable lead isotopes in marine particles. Deep-Sea Res II 47:2257-2279

Bustamante P, Caurant F, Fowler S, Miramand P (1998) Cephalopods as a vector for the transfer of cadmium to top marine predators in the north-east Atlantic Ocean. Sci Total Environ 220:71-80

Bustamante P, González AF, Rocha F, Miramand P, Guerra A (2008) Metal and metalloid concentrations in the giant squid Architeuthis dux from Iberian waters. Mar Environ Res 66:278-287

> Caetano M, Vale C (2003) Trace-elemental composition of seston and plankton along the Portuguese coast. Acta Oecol 24:S341-S349

Caetano M, Fonseca N, Cesário R, Vale C (2007) Mobility of $\mathrm{Pb}$ in salt marshes recorded by total content and stable isotopic signature. Sci Total Environ 380:84-92

Ferreira A, Cortesão C, Castro O, Vale C (1990) Accumulation of metals and organochlorines in tissues of the oyster Crassostrea angulata from the Sado estuary. Sci Total Environ 97-98:627-639

Fiuza A (1983) Upwelling patterns off Portugal. In: Suess E, 
Thide J (eds) Coastal upwelling, its sediment record. Responses of sedimentary regime to present coastal upwelling. Plenum Press, New York, 85-98

Gobeil C, MacDonald R, Smith J, Beaudin L (2001) Atlantic water flow pathways revealed by lead contamination in Artic Basin sediments. Science 293:1301-1304

Guerra A, Cortez T, Rocha F (1999) Redescription of the Chango's octopus, Octopus mimus Gould, 1852, from coastal waters of Chile and Peru (Mollusca, Cephalopoda). Iberus 17:37-57

Ip CCM, Li XD, Zhang G, Wong CSC, Zhang WL (2005) Heavy metals and $\mathrm{Pb}$ isotopic compositions of aquatic organisms in the Pearl River Estuary, South China. Environ Pollut 138:494-504

Komárek M, Ettler V, Chrastný V, Mihaljevic M (2008) Lead isotopes in environmental sciences: a review. Environ Int 34:562-577

Koyama J, Nanamori N, Segawa S (2000) Bioaccumulation of waterborne and dietary cadmium by oval squid, Sepioteuthis lessoniana, and its distribution among organs. Mar Pollut Bull 40:961-967

Kylander M, Weiss D, Cortízas A, Spiro B, Sanchez R, Coles B (2005) Refining the pre-industrial atmospheric $\mathrm{Pb}$ isotope evolution curve in Europe using an 8000 year old peat core from NW Spain. Earth Planet Sci Lett 240: 467-485

Mangold K (1983) Octopus vulgaris. In: Boyle P (ed) Cephalopod life cycles, species accounts, Vol I. Academic Press, London, 335-364

Mangold K (1997) Octopus vulgaris: review of the biology. In: Land MA, Hochberg FG (eds) Proc Workshop on the Fishery and Market Potential of Octopus in California. Smithsonian Institution, Washington, DC, 85-90

Mangold K, von Boletzky S (1973) New data on reproductive biology and growth of Octopus vulgaris. Mar Biol 19:7-12

Marcoux E (1998) Lead isotope systematic of the giant massive sulphide deposits in the Iberian Pyrite Belt. Miner Depos 33:45-58

Martin J, Flegal A (1975) High copper concentrations in squid livers in association with elevated levels of silver, cadmium and zinc. Mar Biol 30:51-55

Miramand P, Bentley D (1992) Concentration and distribution of heavy metals in tissues of two cephalopods, Eledone cirrhosa and Sepia officinalis, from the French coast of the English Channel. Mar Biol 114:407-414

Napoleão P, Pinheiro T, Sousa Reis C (2005) Elemental characterization of tissues of Octopus vulgaris along the Portuguese coast. Sci Total Environ 345:41-49

Nessim R, Riad R (2003) Bioaccumulation of heavy metals in Octopus vulgaris from coastal waters of Alexandria (Eastern Mediterranean). Chem Ecol 19:275-281

Editorial responsibility: Matthias Seaman,

Oldendorf/Luhe, Germany
Palanques A, Diaz JI, Farran M (1995) Contamination of heavy metals in the suspended and surface sediment of the Gulf of Cadiz (Spain): the role of sources, currents, pathways, and sinks. Oceanol Acta 18:469-477

Prego R, Cobelo-Garcia A (2004) Cadmium, copper and lead contamination of the seawater column on the Prestige shipwreck (NE Atlantic Ocean). Anal Chim Acta 524:23-26

Raimundo J, Vale C (2008) Partitioning of Fe, Cu, Zn, Cd and $\mathrm{Pb}$ concentrations among eleven tissues of Octopus vulgaris from the Portuguese coast. Cienc Mar 34:297-305

Raimundo J, Caetano M, Vale C (2004) Geographical variation and partition of metals in tissues of Octopus vulgaris along the Portuguese coast. Sci Total Environ 325:71-81

Raimundo J, Pereira P, Vale C, Caetano M (2005) Fe, Zn, Cu and $\mathrm{Cd}$ in the digestive gland and muscle tissues of Octopus vulgaris and Sepia officinalis from coastal areas in Portugal. Cienc Mar 31:243-251

Raimundo J, Vale C, Duarte R, Moura I (2008) Sub-cellular partitioning of $\mathrm{Zn}, \mathrm{Cu}, \mathrm{Cd}$ and $\mathrm{Pb}$ in the digestive gland of native Octopus vulgaris exposed to different metal concentrations (Portugal). Sci Total Environ 390:410-416

Rantala R, Loring D (1975) A rapid determination of 10 elements in marine suspended matter by atomic absorption spectrophotometry. At Absorp Newsl 16:51-52

Rocha F, Guerra A, González A (2001) A review of reproductive strategies in cephalopods. Biol Rev Camb Philos Soc 76:291-304

Roper CFE, Sweeney MJ, Nauen CE (1984) FAO species catalogue. Volume 3. Cephalopods of the world. FAO Fish Synop 3:1-247

Scheuhammer AM, Templeton DM (1998) Use of stable isotope ratios to distinguish sources of lead exposure in wild birds. Ecotoxicology 7:37-42

Seixas S, Bustamante P, Pierce G (2005) Accumulation of mercury in the tissues of the common octopus Octopus vulgaris (L.) in two localities on the Portuguese coast. Sci Total Environ 340:113-122

> Spencer K, Shafer DJ, Gauldie RW, DeCarlo EH (2000) Stable lead isotope ratios from distinct anthropogenic sources in fish otoliths: a potential nursery ground stock marker. Comp Biochem Physiol A 127:273-284

Sun SS (1980) Lead isotopic study of young volcanic rocks from mid-ocean ridges, ocean islands and island arcs. Philos Trans R Soc Lond A 297:409-445

- Sundby B, Caetano M, Vale C, Gobeil C, Luther G, Nuzzio D (2005) Root-induced cycling of lead in salt marsh sediments. Environ Sci Technol 39:2080-2086

> Windom HL, Schropp SJ, Calder FD, Ryan JD and others (1989) Natural trace metal concentrations in estuarine and coastal marine sediments of the southeastern United States. Environ Sci Technol 23:314-320

Submitted: November 3, 2008; Accepted: April 2, 2009

Proofs received from author(s): June 5, 2009 